\title{
Adult Hippocampal Neurogenesis in Natural Populations of Mammals
}

\author{
Irmgard Amrein \\ Institute of Anatomy, University of Zürich-Irchel, CH-8057 Zürich, Switzerland \\ Correspondence: i.amrein@anatom.uzh.ch
}

This review will discuss adult hippocampal neurogenesis in wild mammals of different taxa and outline similarities with and differences from laboratory animals. It begins with a review of evidence for hippocampal neurogenesis in various mammals, and shows the similar patterns of age-dependent decline in cell proliferation in wild and domesticated mammals. In contrast, the pool of immature neurons that originate from proliferative activity varies between species, implying a selective advantage for mammals that can make use of a large number of these functionally special neurons. Furthermore, rapid adaptation of hippocampal neurogenesis to experimental challenges appears to be a characteristic of laboratory rodents. Wild mammals show species-specific, rather stable hippocampal neurogenesis, which appears related to demands that characterize the niche exploited by a species rather than to acute events in the life of its members. Studies that investigate adult neurogenesis in wild mammals are not numerous, but the findings of neurogenesis under natural conditions can provide new insights, and thereby also address the question to which cognitive demands neurogenesis may respond during selection.

In view of the overwhelming amount of information about molecular and physiological properties of neuronal stem cells, progenitors, and newly born neurons, including their dynamic responses to extrinsic and intrinsic influences, one might wonder why it should be important to investigate adult neurogenesis in natural populations of mammals. With attempts to define the role of adult hippocampal neurogenesis in health and disease in various laboratory mammals, including humans, it has become clear that outcomes of experimental interference with neurogenesis diverge with changing behavioral and genetic contexts. A clear picture of the adaptive value of the observed changes has yet to emerge. Despite the methodological limitations inevitably associated with research performed in wild, genetically heterogeneous mammals, it has the major advantage that the question of functional significance of neurogenesis can be addressed by its adaptive value at the individual, species, and taxa levels. This article is dedicated to research performed in wild animals that live their lives in the contexts of what they have been selected for. The focus will be on hippocampal neurogenesis and presents the findings on (1) the phylogenetic prevalence and the variation of adult

Editors: Fred Gage, Gerd Kempermann, and Hongjun Song

Additional Perspectives on Neurogenesis available at www.cshperspectives.org

Copyright (C) 2015 Cold Spring Harbor Laboratory Press; all rights reserved; doi: 10.1101/cshperspect.a021295

Cite this article as Cold Spring Harb Perspect Biol 2015;7:a021295 
I. Amrein

hippocampal neurogenesis between and within mammalian orders; (2) experimental studies investigating whether wild rodents show neurogenic plasticity comparable to laboratory conspecifics and congeners; and (3) whether variations in hippocampal neurogenesis in wild mammals can be explained by ecological needs associated with natural living conditions.

\section{IS ADULT HIPPOCAMPAL NEUROGENESIS A FEATURE COMMON TO MAMMALS?}

This section provides a comprehensive review of mammals that have been investigated for adult hippocampal neurogenesis (AHN). Although perhaps dreary, it is a useful list if readers are searching for evidence in a given family or order. Reports based on wild or wild-derived mammals are still relatively rare, and, in the species presentation, domesticated mammals other than the commonly used laboratory-bred mice and rats are included as well. Observations in the rodent order will be used as a starting point to which findings in other taxonomic units will be briefly compared. After a short recapitulation of the occurrence of AHN within mammals, the only regulatory mechanism of AHN that is known to apply to most mammals- the age-dependent decline - will be discussed.

\section{Evidence of Hippocampal Neurogenesis in the Order Rodentia}

Of all mammalian taxa, the majority of species investigated for AHN are coming from the rodent order. In the family Muridae (Old World mice and rats, gerbils, and relatives), hippocampal neurogenesis or aspects thereof have been shown in wild yellow-necked wood mice (Apodemus flavicollis [Amrein et al. 2004b]) using Ki67 (Fig. 1A), a protein present during mitosis (Starborg et al. 1996; Scholzen and Gerdes 2000; Kee et al. 2002) and visualization of doublecortin (DCX) (Fig. 1B), a microtubulin-associated protein found in migrating and maturating young neurons (Matsuo et al. 1998; Nacher et al. 2001). Using the same markers, quantitative data have been presented for wild longtailed wood mice (Apodemus sylvaticus [Hauser et al. 2009]) and F1 of wild trapped house mice (Mus musculus domesticus [Klaus et al. 2012]). Using BrdU, cell proliferation was observed in the latter species also by Schaefers (2013). Ki67 and DCX were used in the study of AHN in wild Brown Norway rats (Epp et al. 2009), in laboratory-bred Cairo spiny mice (Acomys cahirinus [Amrein et al. 2011]), and in wild Southern Africa spiny mice (Acomys spinossissimus), Namaqua rock mice (Micaelamys namaquensis), red veld rats (Aethomys chrysophilus), and Highveld
A

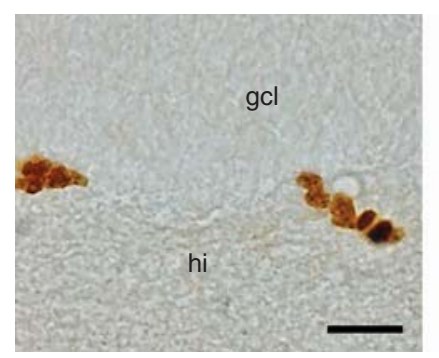

B

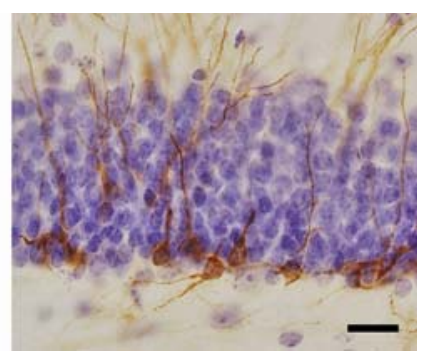

Figure 1. Endogenous markers used for visualizing adult hippocampal neurogenesis (AHN) in wild mammals. Immunopositive cells in the dentate gyrus of wood mice stained for the proliferation marker Ki67 $(A)$ are found in the subgranular layer between granular cell layer $(\mathrm{gcl})$ and hilus (hi) and are often seen in clusters. Young differentiating neurons, immunopositive for doublecortin (DCX) (B) show dendritic branching into the granule cell layer and beyond. The section in $B$ was counterstained with haematoxylin to visualize the granule cell layer. Scale bars, $20 \mu \mathrm{m}$. (From Hauser et al. 2009; reprinted under the terms of the Creative Commons Attribution License, which permits unrestricted use, distribution, and reproduction in any medium, provided the original work is properly cited.) 
gerbils (Tatera brantsii [Cavegn et al. 2013]). Cell proliferation in laboratory-bred gerbils (Meriones unguiculatus) was documented early on using BrdU (Dawirs et al. 1998, 2000).

In the family Cricetidae (New World rats and mice, voles, hamsters, and relatives), proliferating cells in wild American meadow voles (Microtus pennsylvanicus) were labeled by incorporation of injected ${ }^{3} \mathrm{H}$-thymidine (Galea and McEwen 1999) and in laboratory-bred prairie voles (Microtus ochrogaster) by using BrdU combined labeling with glial fibrillary acidic protein (GFAP), Map-2, NeuN, and TuJ1 (Fowler et al. 2002). AHN has been shown using Ki67 and DCX in wild bank voles (Myodes glareolus), and European pine voles (Microtus subterraneus [Amrein et al. 2004b] ). Photoperiod-dependent adult neurogenesis in various brain regions of laboratory-bred golden hamsters (Mesocricetus auratus) was described by Huang et al. (1998) using markers for BrdU in combination with NeuN and GFAP. A similar approach showed AHN in laboratory-bred California mice (Peromyscus californicus [Glasper et al. 2011]).

In the family Sciuridae (squirrels), proliferating cells were found in wild Eastern gray squirrels (Sciurus carolinensis) after injection of BrdU (Lavenex et al. 2000). In a study comparing wild yellow-pine chipmunks (Tamias amoenus) and Eastern gray squirrels, cell proliferation and neuronal fates were visualized immunohistochemically using Ki67 and DCX (Barker et al. 2005). Using the same makers, AHN was compared between two geographically and behaviorally distinct populations of wild red squirrels ( $\mathrm{Ta}$ miasciurus hudsonicus [Johnson et al. 2010]).

AHN has been reported in three wild and laboratory-bred mole-rat species (Amrein et al. 2014; Peragine et al. 2014) of the Bathyergidae family, among them the naked mole rat (Heterocephalus glaber), and in the wild Gambian giant rat (Cricetomys gambianus, family Nesomyidae [Olude et al. 2014]).

Investigations in domesticated and laboratory-bred members of other rodent families reported adult neurogenesis in the hippocampus as well. In guinea pigs (Cavia cavia, family Caviidae), Altman and Das (1967) were the first to show postnatal cell proliferation using ${ }^{3} \mathrm{H}$-thy- midine; whereas, later studies also included adult animals using BrdU in combination with NeuN and GFAP (Guidi et al. 2005). BrdU and PSA-NCAM immunohistochemistry were used to show AHN in laboratory-bred degus (Octodon degus, family Octodontidae [KumazawaManita et al. 2013]).

Evidence of Hippocampal Neurogenesis in Other Wild and Domesticated Mammals

In the order of bats (Chiroptera), AHN has been investigated using markers for Ki67, MCM2, NeuroD, and DCX. Out of 12 species of wild and laboratory-bred echolocation bats (also referred to as Microchiroptera) originating from South America and Africa, AHN was absent in nine species and present at low levels in the remaining three species (Fig. 2) (Amrein et al. 2007). Interestingly, adult neurogenesis is not absent in all neurogenic niches of bats. Newly born neurons are abundant in the subventricular zone (SVZ), and the rostral migratory stream does not qualitatively differ from that seen in rodents (Fig. 2E), but the hippocampus lacks adult-born neurons in most species of the sample (Fig. 2F). The absence of AHN was confirmed in the wild North American brown bat (Eptesicus fuscus [Wojtowicz 2011]), but not in a series of other African bats (Chawana et al. 2014), in which the expression of DCX immunoreactivity depended on the duration of posttrapping handling stress. Interestingly, our laboratory-bred tropical bats that were adapted to human handling and perfused within minutes after catching were also AHN negative using multiple AHN markers (Amrein et al. 2007). In contrast, in megachiropteran species, or fruiteating bats, all animals investigated so far show AHN, albeit at very low levels when compared with rodents. Robust but low numbers of proliferating cells and young neurons were found in wild Wahlberg's epauletted fruit bat (Epomophorus wahlbergi [Gatome et al. 2010]) and in seven additional species of wild megachiropterans (Chawana et al. 2013).

In contrast to low or absent $\mathrm{AHN}$ in bats, high numbers of young cells of the neuronal lineage have been reported in the hippocampus 

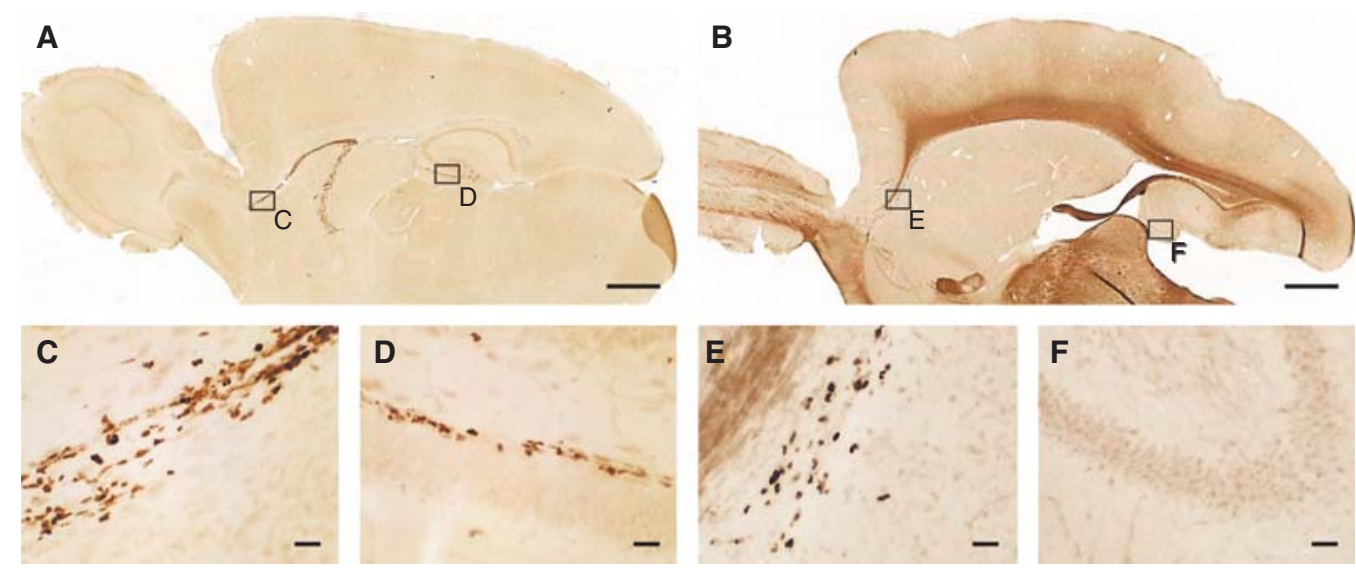

Figure 2. Neurogenic niches in mouse and bats. Mice $(A)$ and echolocating bats $(B)$ show comparable levels of proliferating cells in the subventricular zone (SVZ) and rostral migratory stream $(C, E)$; however, proliferation activity in the hippocampus of bats $(F)$ is completely missing, whereas mice show many proliferating cells in the subgranular layer of the dentate gyrus $(D)$. Proliferating cells are visualized immunohistochemically using Ki67. Scale bars, $1 \mathrm{~mm}(A, B) ; 25 \mu \mathrm{m}(C-F)$. (From Amrein et al. 2007; reprinted, with permission, from the authors.)

of carnivores such as cats (Altman 1963), wild red foxes (Vulpes vulpes [Amrein and Slomianka 2010]), and several dog breeds (Hwang et al. 2007; Siwak-Tapp et al. 2007; De Nevi et al. 2013). Also, AHN has been shown in farmbred mink (Neovison vison [Malmkvist et al. 2012]) and laboratory-bred ferrets (Mustela putorius furo [Takamori et al. 2014]). Quantitative data indicate that wild foxes host 15 times as many young neurons in their dentate gyrus than beagles and, corrected for age (Amrein et al. 2011), far more than rodents.

AHN has been reported in wild Eastern rock sengi (Elephantulus myurus, Order Macroscelidae, also referred to as elephant shrews), an interesting mammal with an allometric hippocampal progression that equals humans (Slomianka et al. 2013). Despite very high numbers of DCX-positive cells, AHN in the sengi does not deviate quantitatively from rodents owing to their exceptional high number of granule cells. In the order of Afrosoricida, AHN has been shown to remain on a surprisingly high level even at old age in laboratory-bred lesser hedgehog tenrec (Echinops telfairi [Alpár et al. 2010]), and appears high-judged by DCX distribution-in an adult wild giant otter shrew (Potamogale velox [Patzke et al. 2013a]).
In the order Artiodactyla (even-toed ungulates), hippocampal cell proliferation has been shown with BrdU and markers against the M1 subunit ribonucleotide reductase (RNR), GFAP, calbindin, neurofilament, and nestin in adult domesticated pigs (Sus domesticus [Zhu et al. 2003; Guidi et al. 2011]) and in sheep (Ovis aries [Zhu et al. 2003]). Using BrdU in combination with Sox2, DCX, NeuN, and S100, the agedependent regulation of AHN in sheep has been investigated in detail (Brus et al. 2013b). Hippocampal proliferation has been shown in rabbits (Oryctolagus cuniculus, order Lagomorpha), using ${ }^{3} \mathrm{H}$-thymidine (Gueneau et al. 1982) and RNR, GFAP, calbindin, neurofilament, and nestin (Zhu et al. 2003). Interestingly, rabbits show neurogenesis in more brain regions than rodents (for review, see Bonfanti and Ponti 2008). Tree shrews (Tupaia glis, order Scandentia) were investigated with BrdU and neuronspecific enolase (NSE) (Gould et al. 1997). Using DCX, young hippocampal neurons have been shown in the largest terrestrial mammal, African elephants (Loxodonta africana, order Proboscidea [Patzke et al. 2013b]).

In the order of Eulipotyphla (the taxonomic order comprising most of the former insectivores), AHN has been shown using Ki67 and 
DCX in wild European moles (Talpa europaea) and hedgehogs (Erinaceus concolor [Bartkowska et al. 2010]) and with BrdU in combination with NeuN in wild common and pygmy shrews (Sorex araneus and Sorex minutus [Bartkowska et al. 2008]). The number of proliferating cells in moles and hedgehogs appear rather low in comparison to rodent data; total granule cell number was, however, not assessed, and a quantitative comparison is therefore difficult. Of interest is that, in shrews, $\mathrm{AHN}$ is literally switched off after the first winter and remains off for the remainder of the animal's life.

In marsupials of the Australian region, AHN has been shown in the laboratory-bred mouse-like fat-tailed dunnart (Sminthopsis crassicaudata, order Dasyuromorphia) based on ${ }^{3} \mathrm{H}$-thymidine incorporation and immunohistochemistry for GFAP, PSA-NCAM, and calbindin (Harman et al. 2003). AHN has also been shown in an American marsupial (order Didelphimorphia), the laboratory-bred gray short-tailed opossum (Monodelphis domestica), using BrdU in combination with NeuN, DCX, and GFAP (Grabiec et al. 2009).

Patzke et al. (2015) presented qualitative evidence of AHN by DCX immunohistochemistry in 71 species, among them from two species out of two orders that have not been investigated before (rock hyrax, order Hyracoidea, and a manatee, order Hyracoidea). Only in the order of Cetacea, they report a lack of DCX-positive cells in the hippocampus of Northern minke whale (Balaenoptera acutorostrata) and harbor porpoise (Phocoena phocoena). Although the lack of neurogenesis is by now almost more interesting than its presence, DCX was the only marker used. DCX staining does show some species differences (Gatome et al. 2010; Slomianka et al. 2013; Amrein et al. 2014) and may be weak when PSA-NCAM generates a strong signal or vice versa. Observations in Cetacea should be confirmed using multiple markers for proliferating cells and differentiating young neurons.

In the order of primates, there is no report on AHN in the suborder of prosimians made up by the lemurs, lorises, pottos, and bushbabies. Several species of the suborder of higher pri- mates, or Anthropoidea, have been investigated. In laboratory-bred New World primates, hippocampal neurogenesis has been reported for the common marmoset (Callithrix jacchus), using BrdU combined with immunohistochemistry against the neuron-specific enolase NSE (Gould et al. 1998) or BrdU in combination with DCX, PSA-NCAM, and GFAP (Marlatt et al. 2011), and in the squirrel monkey (Saimiri sciureus) using BrdU/NeuN labeling (Lyons et al. 2010). In laboratory-bred Old World primates, $\mathrm{AHN}$ was observed in rhesus and cynomolgus monkeys (Macaca mulatta and Macaca fascicularis) by administration of BrdU in combination with extensive immunohistochemistry (TOAD-64, calbindin, NSE, GFAP, PCNA, O4, CNP, NeuN, and TuJ) (Gould et al. 1999; Kornack and Rakic 1999), including detailed age-dependent assessments of AHN and hippocampal principal cell numbers during development and aging in rhesus monkey (Jabès et al. 2010a,b). In Japanese macaques (Macaca fuscata), BrdU was used in combination with markers for Musashi1, Nestin, NeuN, $\beta$-tubulin class III, GFAP, S100- $\beta$, CNP, and GAD (Tonchev et al. 2003). In comparison to rodents, adult primates show markedly lower proliferation rates and a lower number of cells taking a neuronal fate (Tonchev and Yamashima 2006), as well as much longer maturation times of the newly born cells (Ngwenya et al. 2006; Kohler et al. 2011) (for in-depth species comparisons of maturation time in the hippocampus and SVZ in longand short-lived mammals, see Brus et al. 2013a). In the superfamily Hominoidea (gibbons, great apes, and humans), AHN has been documented in humans (Homo sapiens) only: first in cancer patients older than 57 years using BrdU, NeuN, and NSE (Eriksson et al. 1998), during development until the first postnatal year using Ki67 (Seress et al. 2001), and, finally, in one study, covering the entire life span (Knoth et al. 2010). Quantitatively, the human data appear surprisingly close to the observations in Old World primates. It has been calculated that the daily cell proliferation accounts for $0.004 \%$ of total granule cells both in adult macaques (Kornack and Rakic 1999) and adult humans (Spalding et al. 2013). 
I. Amrein

\section{AHN as a Common Trait in Mammals}

In mammals investigated so far, $\mathrm{AHN}$ seems to be the rule with exceptions in the chiropteran and cetacean order. Except for rodents, however, reports are limited to few or only one species per order (Kempermann 2012), and even from only one or two individuals. Despite these limitations, it would be a surprising (and annoying) joke of statistics if AHN proves not to be a widespread mammalian trait. There is, however, still room for a surprise of the type provided by cetaceans and echolocating bats. These exceptions are not of minor importance. Bats, after rodents, are the second-most specious group of mammals and account for $\sim 20 \%$ of all known living mammalian species. A successful evolutionary radiation is possible with and without AHN. Also, AHN can, in fact, be lost. As an energetically demanding process, this would confer a selective advantage to species that lose $\mathrm{AHN}$. That AHN is maintained in many mammals suggests that the advantages that AHN can provide outweigh the costs, providing strong, albeit indirect, evidence for a functional significance of the newly formed cells.

Comparing the Age-Dependent Regulation of Hippocampal Neurogenesis in Wild and Laboratory-Raised Mammals

In comparison to data available from laboratory animals, our knowledge about neurogenesis in wild mammals is limited with regard to aspects of AHN beyond its presence or absence. Comparative approaches to define the adaptive value of adult-generated neurons in vertebrates are still fragmentary (summarized in Barker et al. 2011). Fortunately, one of the most robust findings, the age-dependent decline in neurogenesis described in detail in laboratory rodents (Kuhn et al. 1996; Ben Abdallah et al. 2010), could be assessed on a broad phylogenetic scale-answering the question of whether the decline is a consequence of laboratory housing (Zitnik and Martin 2002) or a natural, age-related change common to both wild and domesticated mammals. When focusing on one structure (hippocampus) in one taxon (mammals), the number of studies that provide quantitative data on different species that can be standardized and compared statistically is relatively small. Analysis is often hampered by methodological problems and how neurogenesis-related data are presented. The problems that have to be overcome in defining age-related changes pertain to practically all studies of AHN in wild animals and will be briefly presented.

Age determinations in wild-derived mammals are not trivial and rarely can achieve the precision available for laboratory species. Age determination in small mammals has been performed using body weight in relation to season in combination with species-specific measures such as tooth wear (Amrein et al. 2004b), or closure of the femoral and humeral epiphyseal plate (Amrein et al. 2007; Gatome et al. 2010). Epp et al. (2009) have used eye lens weights, assessed in both wild rats and laboratory conspecifics of known age, for age estimation. Barker et al. (2003) and Cavegn et al. (2013) combined lens weight with age-dependent structural changes in the number of adhesion lines in the circumferential lamellae of the femur. Even if it may not be possible to arrive at an exact absolute age that would allow direct comparison with laboratory-raised animals, it is at least possible to age wild animals relative to each other in a rather precise manner.

Comparing quantitative data of $\mathrm{AHN}$ in animals that differ a great deal in body and brain size asks for standardization. Finding 1000 young neurons in a dentate gyrus comprising 500,000 mature granule cells implies a different functional weight than finding 1000 young neurons in a hippocampus containing 10 million granule cells. There are large methodological differences in referencing proliferating cells or young cells of neuronal lineage to other measurements-if this is done at all. In the literature, AHN data is often presented as density measurements relative to area or volume. Although such measurements may be useful for withinspecies/within-study comparisons, comparisons across studies and species are seriously hampered. Density is not even a proxy for cell number across commonly used laboratory mouse strains. For example, neuronal density is higher in the dentate gyrus of C57BL/6J than in NZB 
and DBA strains, whereas total granule cell number is actually lowest in C57BL/6 $(\mathrm{Abu}-$ saad et al. 1999). Consequently, we and others assess AHN-related data using design-based stereological methods (West et al. 1991; Schmitz and Hof 2005) and present quantitative data of $\mathrm{AHN}$ as estimates of total numbers and as a percentage of total number of resident granule cells. By doing so, data can be compared between species, and data quality in terms of the precision of cell number estimates can be judged (Slomianka and West 2005).

A comparative analysis on the age-dependent regulation of AHN in wild and laboratory-kept animals (Amrein et al. 2011) was based on such standardized AHN data sets. Surprisingly, on a broad phylogenetic scale, the agedependent down-regulation of hippocampal cell proliferation does not differ between wild and laboratory conspecifics, nor is there a difference between short- and long-lived species or precocial and altricial ones (Fig. 3A) (see Amrein et al. 2011 for the complete list of species). Hippocampal cell proliferation seems to decline chronologically with absolute age in a similar manner in all species, independent from differences in ontogenetic pace. Analyzed for major life history stages (infancy, adolescence, and adulthood), long-lived mammals such as foxes and primates show a significantly lower proliferation rate than rodents at any biologically important stage (Fig. 3B). In a separate analysis, a model of the exponential decline of cell proliferation reveals that $>80 \%$ of the new cells that could possibly be generated during the life span have been born in the hippocampus of both a 6-mo-old mouse and a 30-yr-old human (Lazic 2012). Taken together, the findings imply that an exponential decline of hippocampal proliferation is a phylogenetically fixed trait. With the exception of shrews (Bartkowska et al. 2008), hippocampal proliferation does not cease completely, but continues on a low level throughout late adult life. There is now good evidence that humans do not deviate from this pattern either (Knoth et al. 2010; Spalding et al. 2013). Maintaining a small but constantly dividing cell population in the hippocampus even at old age would indicate that an ontogenetically protract- ed part of the CNS development has turned into a persistent regulated process that appears evolutionarily stable for the majority of mammals. Interestingly, the analysis for the number of young neurons indicates that this part of AHN is less strictly regulated by age; some species such as spiny mice or foxes show a larger variation in the number of young neurons than would be expected from the proliferation data (Amrein et al. 2011). Foxes are proverbially cunning and show exceptional adaptability to natural and man-made environments. Foxes, in which proliferation does not deviate from the rodent data, most likely satisfy the need for young, excitable neurons by extending the maturation phase of the young neurons (Amrein and Slomianka 2010). An extended maturation time has been described in primates as well. A minimum of 6-mo maturation time for young neurons in the primate hippocampus has been reported (Ngwenya et al. 2006; Kohler et al. 2011). Extending the period during which the newly formed neurons show their distinct functional properties (Cameron and McKay 2001; Deng et al. 2009) appears to be an efficient way to serve the adaptive value of AHN despite or as a response to the age-dependent downregulation of cell proliferation.

To date, it is not known how the length of maturation is regulated in different species, nor is it known whether the difference affects only one or several of the stages that the cells pass through — questions that could be addressed in laboratory mice. Understanding the mechanisms of extended neuronal maturation would represent a major breakthrough in AHN research, and provide a new venue for interventive approaches that aim at the modulation of AHN.

\section{NEUROGENIC PLASTICITY IN WILD RODENTS}

Experimental studies often center on the questions of what does alter the extent of AHN, and/ or how behavioral outcomes change in relation to altered AHN. The plasticity of AHN in laboratory rodents in response to experimental conditions is the cornerstone on which numerous research works are based. Usually, these tests last 


\section{Amrein}
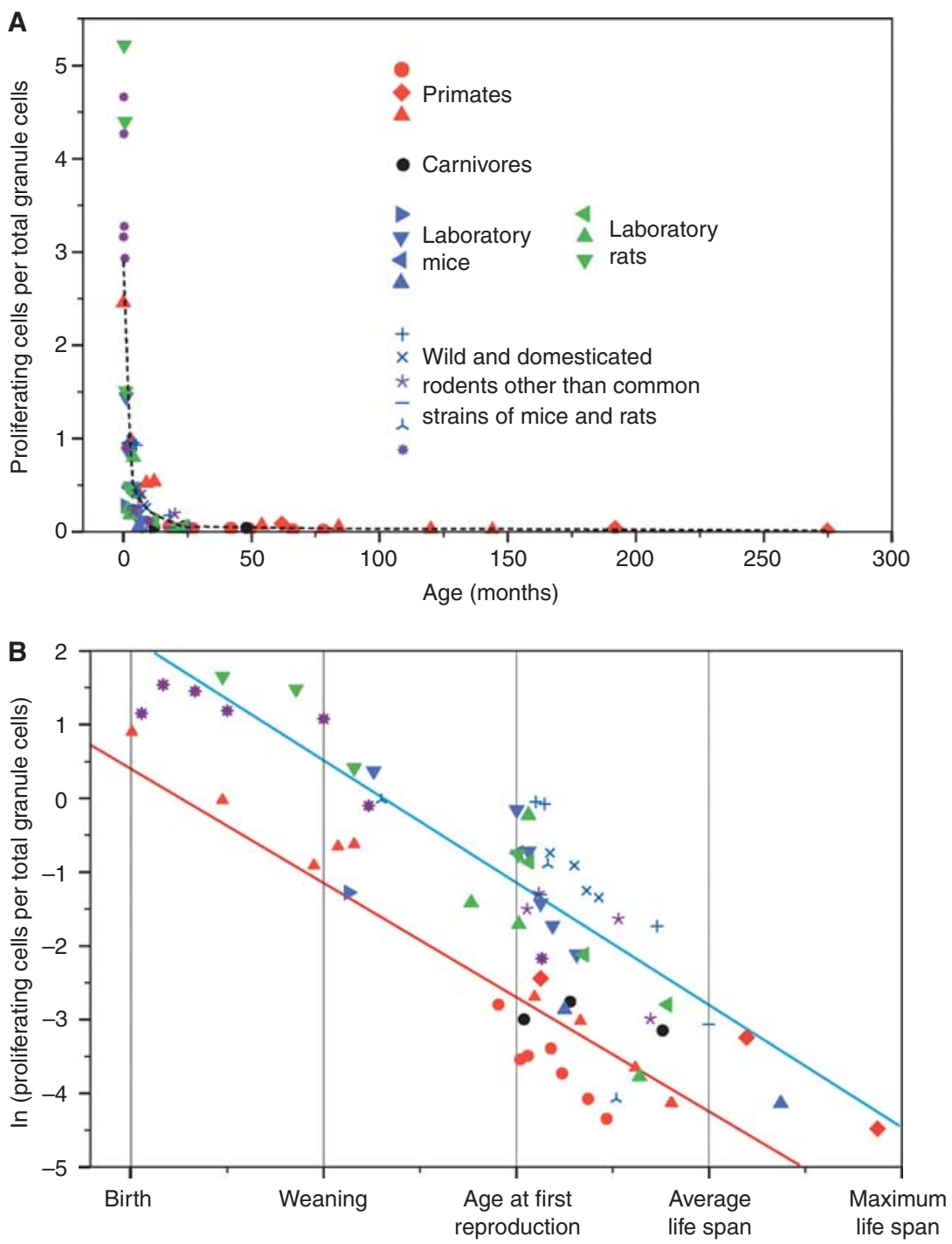

Age normalized to life history stage

Figure 3. Similar decline of cell proliferation with chronological age. (A) Common exponential decline of standardized numbers of proliferating cells (as a percentage of total granule cell number) during aging of laboratory and wild rodents, foxes, and primates. $(B)$ Log-transformed data with respect to major life history stages reveal that primates (red line) and foxes show lower cell proliferation at each stage than rodents (blue line). (From Amrein et al. 2011; adapted, with permission, from John Wiley and Sons (C) 2011.)

for weeks or months to assess all stages of AHN (e.g., to account for the time it takes from cell proliferation to the functional integration of young neurons). Owing to this time lag, a plastic response-in particular in cell proliferation-to a sudden event cannot have immediate fitness consequences under natural living conditions. For wild mammals, harboring a certain number of young, excitable neurons on standby appears more sensible. We would, therefore, expect that $\mathrm{AHN}$ in a wild mammal is tuned to the requirements of its environment in "anticipa- 
tion" of the needs that are to be expected in a particular ecological niche. The following section reviews experiments that investigated AHN plasticity in wild animals along with laboratory animals.

\section{Exercise and $\mathrm{AHN}$ in Wild Mammals}

In the laboratory, experiments that recreate aspects of natural living conditions such as maternal care (Bredy et al. 2003), reproductive experiences from sex (Leuner et al. 2010) to motherhood (Pawluski and Galea 2007; Ruscio et al. 2008), aggressive behaviors (Fiore et al. 2005; Veenema et al. 2005), or social interactions (Fowler et al. 2002; Hoshaw et al. 2006; Lagace et al. 2010) can modulate neurogenesis in laboratory rodents-whether positive or negative is surprisingly often a question of species, strain, gender, or social structure (reviewed by Lieberwirth and Wang 2012). Environmental enrichment (Kempermann et al. 1997) and physical activity (van Praag et al. 1999), also inevitable parts of natural life, usually increase AHN in laboratory rodents, a finding that has been replicated by many laboratories (for review, see Kempermann et al. 2010; Klaus and Amrein 2012; Klaus et al. 2012). It has been suggested that the individual neurogenic response to exercise in laboratory mice is related to the size of the dentate gyrus (Llorens-Martín et al. 2006). To investigate whether physical exercise can modulate $\mathrm{AHN}$ in free-living rodents, wild long-tailed wood mice (Apodemus sylvaticus) and wild house mice with low basal neurogenesis were tested along with laboratory mice under the same exercise conditions. Voluntary running increases proliferation and neuronal differentiation in laboratory mice, but not in wild wood mice (Hauser et al. 2009) or wild house mice (see Fig. 5) (Klaus et al. 2012). There was also no correlation between activity and AHN as found in some laboratory mice (summarized in Klaus and Amrein 2012), despite extreme interindividual activity differences in the wild mice. It has been argued that a ceiling effect could apply to the regulation of AHN in the wild rodents, as wood mice are known to be physically very active (Niethammer and Krapp
1982). The data do not support this hypothesis. Wild-derived wood mice housed in normal laboratory cages with no running wheel for 2 weeks should experience an impoverished environment. A decrease in AHN would be expected, but was not observed. After 2 wk of laboratory housing, running and sedentary wild wood mice show exactly the same extent of AHN as wood mice analyzed immediately after trapping, suggesting that a constant pool of functionally distinct young neurons is maintained in these small rodents, despite environmental changes and experimental challenges (Hauser et al. 2009). Also, the basal AHN in wild house mice is surprisingly low. C57BL/6 show $\sim 5$ times higher numbers of proliferating cells and $\sim 2$ times more young cells of the neuronal lineage than age-matched wild house mice (Klaus et al. 2012). Despite these relatively low levels, running does not lead to a significant increase in AHN in wild house mice, an observation that has been replicated by others (Schaefers 2013).

\section{Reduced Context Sensitivity in Wild Mammals}

In laboratory rodents, the positive effect of physical exercise on AHN can be lost if the activity is not entirely voluntary. Treadmill running influences AHN positively only up to a certain speed; high-speed forced treadmill running reverses the positive effect (Kim et al. 2003; Lou et al. 2008). Conditions creating a necessity for the animal to run (e.g., if laboratory mice were given their daily food only after a certain distance run) kept proliferation at basal levels, even though the distance that was run was the same as under voluntary conditions (Klaus et al. 2012). The emotional valence, or hedonic value (Leuner et al. 2010) of a given context can attenuate or even reverse a common regulatory mechanism for AHN in laboratory rodents, and increasing evidence indicates that the animals emotional state at the time when the new neurons are born impact on the responsiveness and fate of the young cells later on (Glasper et al. 2012; Groves et al. 2013). An evolutionary adaptation to the sum of aversive and appetitive stimuli characteristic for an ecological niche 


\section{Amrein}

makes it understandable why context sensitivity is not apparent in wild animals. Wild house mice exposed to the "running for food" experiment (Fig. 4) do not show altered AHN relative to controls (Klaus et al. 2012), and environmental changes, as described above, do not change AHN extent in the wild wood mice. There is evidence that this stability is not only apparent over the 2 wk of experimental time as in the studies discussed above. Stable AHN has also been reported in squirrels despite seasonally varying requirements for spatial memory processing (Lavenex et al. 2000). In contrast, changes in hippocampal volume in relation to season and gender have been reported in wild Richardson's ground squirrel (Burger et al. 2013). Fur- ther investigations are therefore needed, but the apparent lack of AHN response to seasonally changing requirements in wild mammals is in striking contrast to the strong seasonal recruitment of young neurons found in birds (for comparative reviews, see Barker et al. 2011; Grandel and Brand 2013). Interindividual AHN variation of control and experimentally challenged wild mammals is surprisingly small, despite their presumably large genetic variability, large individual differences in behavioral performance, and variable age (see Fig. 4). In theory, trapping itself is a selective procedure that may generate a bias toward a specific group of animals from the species under investigation. This is most likely not the case, as in the F1 of

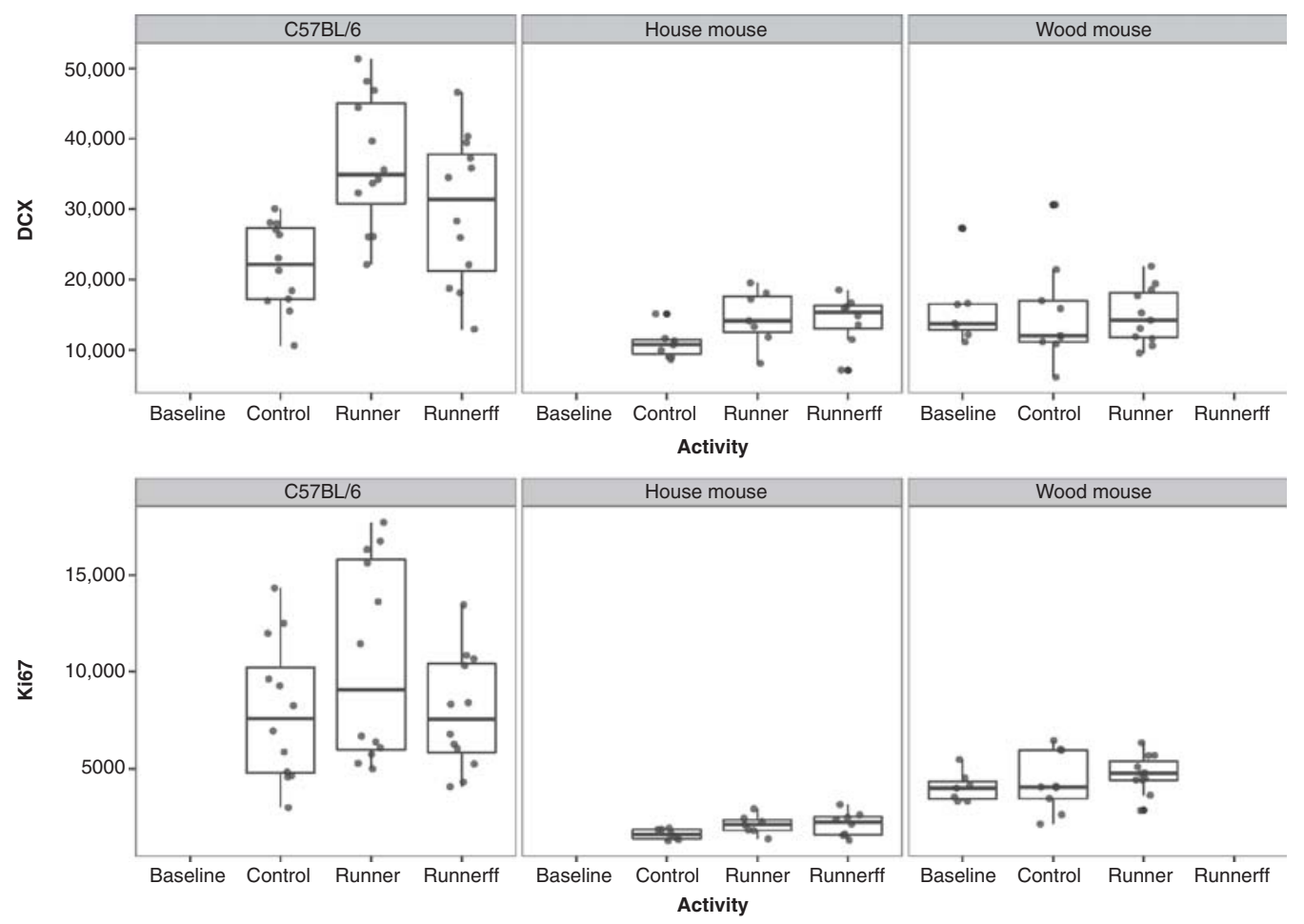

Figure 4. AHN stability in wild versus plasticity in laboratory rodents. High individual variability in the number of proliferating cells (Ki67) and young neurons (DCX) owing to experimental challenges in the running C57BL/ 6 stands in contrast to stable AHN with low interindividual variability in age-matched F1 of wild house mice and wild long-tailed wood mice. The experimental effect of voluntary running on AHN is significant in C57BL/6, but not in house mice or wood mice. If rodents have to run to get their food, running becomes a necessity, and running for food (runnerff) counteracts the positive effect of physical activity on AHN in C56BL/6, but not in wild house mice. Baseline: wild mice investigated right after trapping. (Data from Hauser et al. 2009 and Klaus et al. 2012.) 
wild house mice, bred in captivity, small interindividual AHN variation can be observed as well. How can the context sensitivity of AHN in laboratory rodents be explained? Continuous physical stimulation leads to an epigenetic modification in the dentate gyrus after $4 \mathrm{wk}$ of voluntary exercise in laboratory rats (Collins et al. 2009), coinciding with an attenuation of AHN after long-term exercise (Naylor et al. 2005). Also, laboratory mice of two different strains that were exposed to an enriched environment early in development show stable AHN when challenged as adults in a running experiment (Schaefers 2013). It would be premature to conclude that contextual and physical stimulations or the lack thereof in early development predict whether challenges later in life lead to a plastic response of AHN. As shown by Schaefers (2013), rearing offspring of wild-derived house mice in a deprived environment is not sufficient to induce plasticity of AHN at later ages. During domestication of laboratory rodents, genetic and epigenetic alterations may have led to the persisting opening of pathways in AHN regulation. In contrast, plastic changes of AHN are not, or only partially, operative in freeliving individuals, indicating that wild rodents show species-specific AHN levels that do not respond or respond weakly to momentary shifts in activity, environment, context, or cognitive requirements. The species-specific AHN levels can differ quite substantially between close and distant phylogenetic groups; its variation by far exceeds experimentally induced alterations of AHN. The next section will discuss the evidence for differences and similarities explained by specific ecological requirements and the sharing of common traits.

\section{FUNCTIONAL ASPECTS OF HIPPOCAMPAL NEUROGENESIS VARIATION IN WILD MAMMALS}

Based on the experiments described so far, we suggest that AHN in wild mammals is finetuned to the demands characteristic for the species niche. We thus turn again to basal AHN on a species level and discuss findings that are shared between species.

\section{"Use It or Lose It" in Free-Living Mammals}

Shors et al. (2012) have formulated the "use-itor-lose-it" concept for AHN in laboratory rodents, as many behavioral experiments that include some forms of learning increase the survival rates of young cells. Free-living mammals have to cope with a multitude and, in many ways, continually changing stimuli throughout their life. On a narrow phylogenetic scale, there is evidence that the extent and onset of the agedependent down-regulation of AHN can differ in wild rodents. In voles, similar to laboratory rodents, AHN declines steadily (Amrein et al. 2004b). Wild rats show higher levels of AHN than laboratory-kept rats at young age, but it becomes indistinguishable after $\sim 2$ mo of age (Epp et al. 2009). In hedgehog tenrecs (Alpár et al. 2010), Namaqua rock mice (Cavegn et al. 2013), and wood mice (Amrein et al. 2004b), AHN declines slower than in laboratory mice until average life expectancy, and even older animals retain a relatively high $\mathrm{AHN}$. Wood mice do not only have a higher level of AHN, but also differ from voles in their learning abilities. They adapt faster to new environments and show increased efficiency in place learning and reversal than voles (Galsworthy et al. 2002). This agrees well with the complexity of the ecological niche and habitat requirements of the animals. Small, homogeneous territories (voles and house mice) are associated with low AHN that declines fast with age. Complex territories with overlapping home ranges of individuals (wood mice and rock mice) are associated with a high level of AHN that declines at a slower rate.

\section{The Energetic Trade-Off Under Natural Conditions}

Cell proliferation is an energetically expensive endeavor (Vander Heiden et al. 2009), and the generation, differentiation, and subsequent elimination of a large number of young neurons might be maintained if energy is not limited. Any of these processes could become a regulatory target under conditions of scarce nutrients or biological processes with high-energy demands. An efficient way to make the most of 
I. Amrein

AHN in hard times is keeping proliferation low and increasing the survival of the young neurons. Dietary restriction in laboratory rats and mice does indeed increase the survival of newly born neurons without affecting cell proliferation (Lee et al. 2000, 2002). In wild rodents living in a challenging environment, two energy-saving strategies, low proliferation and high numbers of young neurons were found (Cavegn et al. 2013). Likewise, pregnancy and lactation are heavy energetic burdens on small mammals, and studies in laboratory rodents report a decrease in AHN during gestation and the postpartum period, with a recovery of AHN to baseline levels after weaning (Leuner et al. 2007; Pawluski and Galea 2007; Kim et al. 2010). Also, reproductively active wild female meadow voles show lower proliferation compared with both males and reproductively inactive females (Galea and McEwen 1999; Ormerod and Galea 2001). The reduction in AHN is not necessarily limited to the lactating mother. In Californian mice in which females and males are engaged in the care for pups, both parents show reduced AHN, notably without showing decreased performance in behavioral tests (Glasper et al. 2011), similar to the AHN reduction in the social prairie vole fathers (Lieberwirth et al. 2013). In wild Namaqua rock mice, previous reproduction led to a permanent reduction in AHN. Females that had at least one pregnancy in the former breeding season show lower AHN than males (Cavegn et al. 2013); mole-rat breeders are also lower in neurogenesis than nonbreeding individuals in the eusocial naked mole rats (Peragine et al. 2014). Breeding pressure, combined with scarce nutrients during winter, might limit the recovery of AHN permanently. Under natural living conditions, shrews are the only species so far in which AHN terminates completely after the first half of their life, despite the fact that dormant precursor cells can reenter cell cycle under experimental conditions (Bartkowska et al. 2008). The attenuation is observed in both sexes, and there is also no evidence that the down-regulation is hormonally controlled. The biological advantage of this elimination is not clear; an energy-saving strategy would, however, be reasonable as Sorex have a metabolic rate that is close to the physiological limits (Ochocińska and Taylor 2005).

\section{Spatial Navigation Skills Do Not Correlate with Hippocampal Neurogenesis}

Inasmuch as space is an inevitable part of the formation of episodic memories, spatial orientation must be associated with a functioning hippocampus ( for an excellent comparative review on spatial learning and hippocampus, see Lee et al. 1998). The contribution of young neurons to this behavior in wild mammals is far from clear. Early on, increased AHN in rodents that occupy large territories was observed (Amrein et al. 2004b), a finding that corresponded well with the initial reports that hippocampaldependent spatial learning (Moser et al. 1995) is improved in mice with higher AHN (Kempermann and Gage 2002). Several works using ablation strategies in which AHN was eliminated by irradiation or by constitutive or inducible transgenic approaches failed to show an effect on spatial learning in the Morris water maze (summarized in Marín-Burgin and Schinder 2012). Likewise, a meta-analysis of probe trial data as a measure of spatial memory in the water maze found no relationship between behavioral performance and ablated AHN (Groves et al. 2013). Also in wild animals, only weak or no correlations have been found between AHN and markedly different hoarding behavior between geographically separated populations of squirrels (Johnson et al. 2010) or between species (Barker et al. 2005). Gender-specific variations of territory size in sengis (Slomianka et al. 2013), wild wood mice (Amrein et al. 2004a,b), and Namaqua rock mice (Cavegn et al. 2013) are not mirrored in AHN differences once total granule cell number is taken into account. The relation between spatial learning and AHN might depend critically on the complexity of the environment, which can, but not necessarily has to be, associated with the absolute size of the home range. The case of echolocating bats and cetaceans with their needs in home range and migratory navigation makes a strong point that $\mathrm{AHN}$ is not required for precise spatial orientation in their niche. An issue that has not been 
addressed so far is that echolocating bats have relatively smaller hippocampi than megachiropteran species (Baron et al. 1996), and also, in whales, the hippocampus is surprisingly small (Jacobs et al. 1979; Marino 2007) with a "very diminutive dentate gyrus" (Hof and Van Der Gucht 2007). The quantitative relations between hippocampal principal cell numbers are strikingly different in convergence and divergence between species (Slomianka et al. 2013), and a full understanding of the functionality of newly born neurons on a phylogenetic scale may only be gained if we consider these neurons in the context of the functional circuitry in which they are integrated.

\section{The Emergence of Habitat-Specific Patterns in Basal Neurogenesis}

An ecological niche with a high likelihood of variations in the spatial and temporal distribu-
Adult Hippocampal Neurogenesis in Mammals

tion of food resources, conspecifics, and predators requires high behavioral flexibility from its inhabitant. As a consequence, we and others have argued that AHN might contribute to behavioral flexibility (Amrein et al. 2007; Amrein and Lipp 2009; Garthe et al. 2009). A comparison of 11 rodent species originating from different habitats supports this hypothesis. When analyzing four mouse species from a cold European habitat, four mouse species from Southern Africa, a habitat that is characterized by dry seasons and high temperature variations $(\mathrm{Ca}-$ vegn et al. 2013), and three strictly subterranean mole-rat species (Amrein et al. 2014), it becomes apparent that mole rats living in their relatively stable, protected tunnel system have the lowest $\mathrm{AHN}$, rodents from the European climate take an intermediate position, and the highest AHN is observed in the South African surface-dwelling rodents (Fig. 5). The habitats were chosen because of the manifold differences

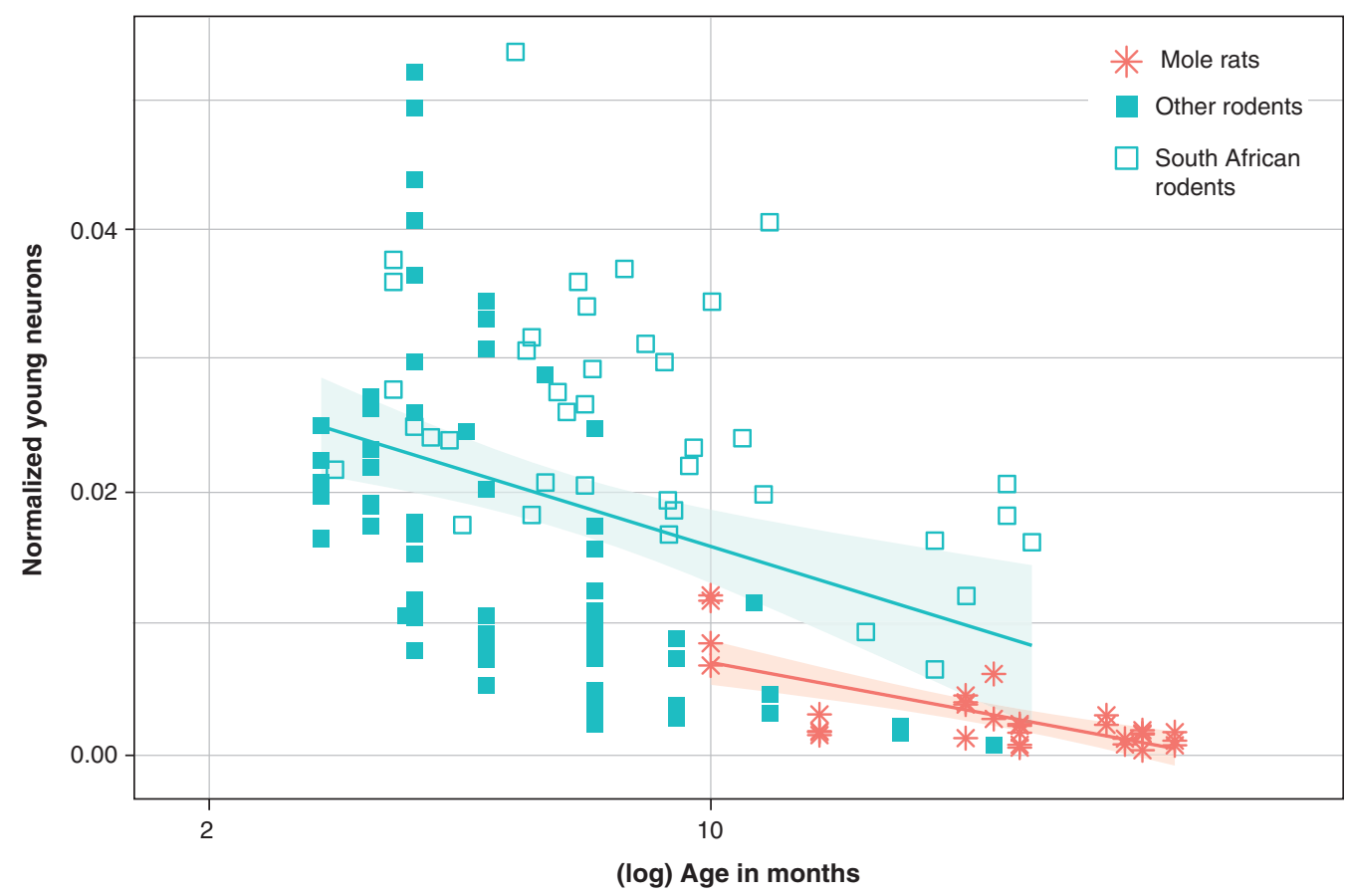

Figure 5. Habitat pattern of basal AHN in rodents. Estimated numbers of young neurons (DCX ${ }^{+}$or PSA$\mathrm{NCAM}^{+}$) as a percentage of total granule cells (normalized young neurons) relative to tentative age are markedly lower in subterranean mole rats compared with surface-dwelling rodents. Within the surface-dwelling rodents, the South African species from an environmental challenging habitat form their own cluster. (Data from Amrein et al. 2011, 2014; Cavegn et al. 2013.) 
I. Amrein

in ecological parameters, of which temperature and rainfall variations (Peel et al. 2007) with the associated fluctuations in food resources are probably the most important factors. It is known that environmental challenges for small mammals in hot and dry conditions exceed the ones for animals living in cold climates (e.g., the upper critical temperature for an euthermal mammal is less variable than the lower critical temperature), and also water conservation requires extensive adaptations on the physiological and behavioral level (Merritt 2010). Mole rats deal with temperature variations by digging deep blind tunnels for thermoregulation (Jarvis and Bennett 1991). Whether the sum of all ecological factors or certain aspects thereof impact AHN remains an open question. As the eight surface-dwelling species are members of three murine subfamilies, we could test for the phylogenetic impact on AHN. The analysis showed that phylogenetic relatedness does not explain the observed variability of AHN. The data indicate that basal AHN becomes a target of concerted shifts that can be assigned to selective pressures associated with varying habitats. Interestingly, such a concerted shift has been shown for life expectancy and mating behavior in males of 52 insectivorous marsupial species in response to food availability; the latter is a function of latitude of the habitat, ranging from grassland to forest (Fisher et al. 2013). Based on the findings in wild mammals, we hypothesize that species-specific regulation of AHN and, of cellular stages, most likely the immature DCXor PSA-NCAM-positive neuron, are the substrates for adaptive responses to environmental challenges. Following the call for a more naturalistic perspective on the concept of AHN function (Kempermann 2012), more quantitative data on AHN in various species, including relevant ecological factors, are needed to verify whether our observations are taxon-specific or can be generalized to a wider range of mammals.

\section{OUTLOOK INTO THE WILD}

Belyaev (1979) formulated the idea that domestication destabilizes regulatory systems that, in wild conspecifics, are tightly tuned to the envi- ronmental conditions to which the species is adapted. Domestication alters the phenotype, behavior, and brain size in many mammals including rodents (Kruska 1988) and induces changes in, for example, neuroendocrine and neurotransmitter systems (Trut et al. 2009). These systems have been shown to be important players in the modulation of AHN (McEwen et al. 2002; Pathania et al. 2010). Consequently, the high plasticity of AHN in laboratory rodents might be enabled by processes linked to domestication. As reviewed here, AHN in wild members of mammalian species is surprisingly stable. The plasticity in the regulation of neurogenesis in domesticated mammals and the lack thereof in wild mammals are the first issues that could be addressed in future research. Second, species-specific variations in the maturation length of immature neurons could be investigated for their functional impact. Third and last, if we assume that AHN in mammals has similar functions across phylogenetic groups and during ontogenetic development, we have to find a causal relation that is robust to the age-dependent decline and, in terms of life history pace, robust to dramatic differences in the numerical availability of young neurons between shortlived and long-lived mammals.

\section{ACKNOWLEDGMENTS}

I thank Lutz Slomianka for helpful suggestions and critical discussions, Shihhui Huang and Maarten van Dijk for preparing figures, and the Swiss National Science Foundation (Grant No.31003A_141244/1) for financial support.

\section{REFERENCES}

\footnotetext{
Abusaad I, MacKay D, Zhao J, Stanford P, Collier DA, Everall IP. 1999. Stereological estimation of the total number of neurons in the murine hippocampus using the optical disector. J Comp Neurol 408: 560-566.

Alpár A, Künzle H, Gärtner U, Popkova Y, Bauer U, Grosche J, Reichenbach A, Härtig W. 2010. Slow age-dependent decline of doublecortin expression and BrdU labeling in the forebrain from lesser hedgehog tenrecs. Brain Res 1330: 9-19.

Altman J. 1963. Autoradiographic investigation of cell proliferation in the brains of rats and cats. Anat Rec 145: $573-591$.
} 
Altman J, Das GD. 1967. Postnatal neurogenesis in the guinea-pig. Nature 214: 1098-1101.

Amrein I, Lipp H-P. 2009. Adult hippocampal neurogenesis of mammals: Evolution and life history. Biol Lett 5: 141144.

Amrein I, Slomianka L. 2010. A morphologically distinct granule cell type in the dentate gyrus of the red fox correlates with adult hippocampal neurogenesis. Brain Res 1328: $12-24$.

Amrein I, Slomianka L, Lipp HP. 2004a. Granule cell number, cell death and cell proliferation in the dentate gyrus of wild-living rodents. Eur J Neurosci 20: $3342-$ 3350.

Amrein I, Slomianka L, Poletaeva II, Bologova NV, Lipp HP. 2004b. Marked species and age-dependent differences in cell proliferation and neurogenesis in the hippocampus of wild-living rodents. Hippocampus 14: 10001010.

Amrein I, Dechmann DK, Winter Y, Lipp HP. 2007. Absent or low rate of adult neurogenesis in the hippocampus of bats (Chiroptera). PLoS ONE 2: e455.

Amrein I, Isler K, Lipp H-P. 2011. Comparing adult hippocampal neurogenesis in mammalian species and orders: Influence of chronological age and life stage. Eur J Neurosci 34: 978-987.

Amrein I, Becker AS, Engler S, Huang SH, Müller J, Slomianka L, Oosthuizen MK. 2014. Adult neurogenesis and its anatomical context in the hippocampus of three molerat species. Front Neuroanat 8: 39.

Barker JM, Boonstra R, Schulte-Hostedde AI. 2003. Age determination in yellow-pine chipmunks (Tamias amoenus): A comparison of eye lens masses and bone sections. Can J Zool 81: 1774-1779.

Barker JM, Wojtowicz JM, Boonstra R. 2005. Where's my dinner? Adult neurogenesis in free-living food-storing rodents. Genes Brain Behav 4: 89-98.

Barker JM, Boonstra R, Wojtowicz JM. 2011. From pattern to purpose: How comparative studies contribute to understanding the function of adult neurogenesis. Eur $J$ Neurosci 34: 963-977.

Baron G, Stephan H, Frahm HD. 1996. Comparative neurobiology in Chiroptera: Macromorphology, brain structures, tables and atlases. Birkhäuser, Basel, Switzerland.

Bartkowska K, Djavadian RL, Taylor JRE, Turlejski K. 2008. Generation recruitment and death of brain cells throughout the life cycle of Sorex shrews (Lipotyphla). Eur J Neurosci 27: $1710-1721$.

Bartkowska K, Turlejski K, Grabiec M, Ghazaryan A, Yavruoyan E, Djavadian RL. 2010. Adult neurogenesis in the hedgehog (Erinaceus concolor) and mole (Talpa europaea). Brain Behav Evol 76: 128-143.

Belyaev DK. 1979. Destabilizing selection as a factor in domestication. J Hered 70: 301-308.

Ben Abdallah NMB, Slomianka L, Vyssotski AL, Lipp H-P. 2010. Early age-related changes in adult hippocampal neurogenesis in C57 mice. Neurobiol Aging 31: 151-161.

Bonfanti L, Ponti G. 2008. Adult mammalian neurogenesis and the New Zealand white rabbit. Vet J 175: 310-331.

Bredy TW, Grant RJ, Champagne DL, Meaney MJ. 2003. Maternal care influences neuronal survival in the hippocampus of the rat. Eur J Neurosci 18: 2903-2909.
Brus M, Keller M, Levy F. 2013a. Temporal features of adult neurogenesis: Differences and similarities across mammalian species. Front Neurosci 7: e135.

Brus M, Meurisse M, Gheusi G, Keller M, Lledo PM, Lévy F. 2013b. Dynamics of olfactory and hippocampal neurogenesis in adult sheep. J Comp Neurol 521: 169-188.

Burger DK, Saucier JM, Iwaniuk AN, Saucier DM. 2013. Seasonal and sex differences in the hippocampus of a wild rodent. Behav Brain Res 236: 131-138.

Cameron H, McKay R. 2001. Adult neurogenesis produces a large pool of new granule cells in the dentate gyrus. $J$ Comp Neurol 435: 406-417.

Cavegn N, van Dijk RM, Menges D, Brettschneider H, Phalanndwa M, Chimimba CT, Isler K, Lipp H-P, Slomianka L, Amrein I. 2013. Habitat-specific shaping of proliferation and neuronal differentiation in adult hippocampal neurogenesis of wild rodents. Front Neuroscience 7: 59.

Chawana R, Patzke N, Kaswera C, Gilissen E, Ihunwo AO, Manger PR. 2013. Adult neurogenesis in eight Megachiropteran species. Neuroscience 244: 159-172.

Chawana R, Alagaili A, Patzke N, Spocter MA, Mohammed OB, Kaswera C, Gilissen E, Bennett NC, Ihunwo AO, Manger PR. 2014. Microbats appear to have adult hippocampal neurogenesis, but post-capture stress causes a rapid decline in the number of neurons expressing doublecortin. Neuroscience 277: 724-733.

Collins A, Hill LE, Chandramohan Y, Whitcomb D, Droste SK, Reul JMHM. 2009. Exercise improves cognitive responses to psychological stress through enhancement of epigenetic mechanisms and gene expression in the dentate gyrus. Plos ONE 4: e4330.

Dawirs RR, Hildebrandt K, Teuchert-Noodt G. 1998. Adult treatment with haloperidol increases dentate granule cell proliferation in the gerbil hippocampus. J Neural Transm 105: 317-327.

Dawirs RR, Teuchert-Noodt G, Hildebrandt K, Fei F. 2000. Granule cell proliferation and axon terminal degradation in the dentate gyrus of gerbils (Meriones unguiculatus) during maturation, adulthood and aging. J Neural Transm 107: 639-647.

De Nevi E, Marco-Salazar P, Fondevila D, Blasco E, Pérez L, Pumarola M. 2013. Immunohistochemical study of doublecortin and nucleostemin in canine brain. Eur J Histochem 57: e9.

Deng W, Saxe MD, Gallina IS, Gage FH. 2009. Adult-born hippocampal dentate granule cells undergoing maturation modulate learning and memory in the brain. J Neurosci 29: 13532-13542.

Epp JR, Barker JM, Galea LAM. 2009. Running wild: Neurogenesis in the hippocampus across the lifespan in wild and laboratory-bred Norway rats. Hippocampus 19: $1040-1049$.

Eriksson PS, Perfilieva E, Bjork-Eriksson T, Alborn AM, Nordborg C, Peterson DA, Gage FH. 1998. Neurogenesis in the adult human hippocampus. Nat Med 4: 13131317.

Fiore M, Amedola T, Triaca V, Alleva E, Aloe L. 2005. Fighting in the aged male mouse increases the expression of TrkA and TrkB in the subventricular zone and in the hippocampus. Behav Brain Res 157: 351-362. 
Fisher DO, Dickman CR, Jones ME, Blomberg SP. 2013. Sperm competition drives the evolution of suicidal reproduction in mammals. Proc Natl Acad Sci 110: 1791017914.

Fowler CD, Liu Y, Ouimet C, Wang Z. 2002. The effects of social environment on adult neurogenesis in the female prairie vole. J Neurobiol 51: 115-128.

Galea LAM, McEwen BS. 1999. Sex and seasonal differences in the rate of cell proliferation in the dentate gyrus of adult wild meadow voles. Neuroscience 89: 955-964.

Galsworthy MJ, Paya-Cano JL, Monleon S, Plomin R. 2002. Evidence for general cognitive ability $(g)$ in heterogeneous stock mice and an analysis of potential confounds. Genes Brain Behav 1: 88-95.

Garthe A, Behr J, Kempermann G. 2009. Adult-generated hippocampal neurons allow the flexible use of spatially precise learning strategies. PLOS ONE 4: e5464.

Gatome CW, Mwangi DK, Lipp HP, Amrein I. 2010. Hippocampal neurogenesis and cortical cellular plasticity in Wahlberg's epauletted fruit bat: A qualitative and quantitative study. Brain Behav Evol 76: 116-127.

Glasper ER, Kozorovitskiy Y, Pavlic A, Gould E. 2011. Paternal experience suppresses adult neurogenesis without altering hippocampal function in Peromyscus californicus. $J$ Comp Neurol 519: 2271-2281.

Glasper ER, Schoenfeld TJ, Gould E. 2012. Adult neurogenesis: Optimizing hippocampal function to suit the environment. Behav Brain Res 227: 380-383.

Gould E, McEwen BS, Tanapat P, Galea LAM, Fuchs E. 1997. Neurogenesis in the dentate gyrus of the adult tree shrew is regulated by psychosocial stress and NMDA receptor activation. J Neurosci 17: 2492-2498.

Gould E, Tanapat P, McEwen B, Flügge G, Fuchs E. 1998. Proliferation of granule cell precursors in the dentate gyrus of adult monkeys is diminished by stress. Proc Natl Acad Sci 95: 3168-3171.

Gould E, Reeves AJ, Graziano MS, Gross CG. 1999. Neurogenesis in the neocortex of adult primates. Science 286: $548-552$.

Grabiec M, Turlejski K, Djavadian RL. 2009. The partial 5 HT1A receptor agonist buspirone enhances neurogenesis in the opossum (Monodelphis domestica). Eur Neuropsychopharmacol 19: 431-439.

Grandel H, Brand M. 2013. Comparative aspects of adult neural stem cell activity in vertebrates. Dev Genes Evol 223: $131-147$.

Groves JO, Leslie I, Huang G-J, McHugh SB, Taylor A, Mott R, Munafò M, Bannerman DM, Flint J. 2013. Ablating adult neurogenesis in the rat has no effect on spatial processing: Evidence from a novel pharmacogenetic model. PLoS Genet 9: e1003718.

Gueneau G, Privat A, Drouet J, Court L. 1982. Subgranular zone of the dentate gyrus of young rabbits as a secondary matrix. A high-resolution autoradiographic study. Dev Neurosci 5: 345-358.

Guidi S, Ciani E, Severi S, Contestabile A, Bartesaghi R. 2005. Postnatal neurogenesis in the dentate gyrus of the guinea pig. Hippocampus 15: 285-301.

Guidi S, Bianchi P, Alstrup AKO, Henningsen K, Smith DF, Bartesaghi R. 2011. Postnatal neurogenesis in the hippo- campal dentate gyrus and subventricular zone of the Göttingen minipig. Brain Res Bull 85: 169-179.

Harman A, Meyer P, Ahmat A. 2003. Neurogenesis in the hippocampus of an adult marsupial. Brain Behav Evol 62: $1-12$.

Hauser T, Klaus F, Lipp H-P, Amrein I. 2009. No effect of running and laboratory housing on adult hippocampal neurogenesis in wild caught long-tailed wood mouse. BMC Neurosci 10: 43.

Hof PR, Van Der Gucht E. 2007. Structure of the cerebral cortex of the humpback whale, Megaptera novaeangliae (Cetacea, Mysticeti, Balaenopteridae). Anat Rec 290: $1-$ 31.

Hoshaw BA, Evans JC, Mueller B, Valentino RJ, Lucki I. 2006. Social competition in rats: Cell proliferation and behavior. Behav Brain Res 175: 343-351.

Huang L, DeVries GJ, Bittman EL. 1998. Photoperiod regulates neuronal bromodeoxyuridine labeling in the brain of a seasonally breeding mammal. J Neurobiol 36: 410420.

Hwang IK, Yoo KY, Li H, Choi JH, Kwon YG, Ahn Y, Lee IS, Won MH. 2007. Differences in doublecortin immunoreactivity and protein levels in the hippocampal dentate gyrus between adult and aged dogs. Neurochem Res 32: 1604-1609.

Jabès A, Lavenex PB, Amaral DG, Lavenex P. 2010a. Postnatal development of the hippocampal formation: A stereological study in Macaque monkeys. J Comp Neurol 519: 1051-1070.

Jabès A, Lavenex PB, Amaral DG, Lavenex P. 2010b. Quantitative analysis of postnatal neurogenesis and neuron number in the macaque monkey dentate gyrus. Eur $J$ Neurosci 31: 273-285.

Jacobs MS, McFarland WL, Morgane PJ. 1979. The anatomy of the brain of the Bottlenose dolphin (Tursiops truncatus). Rhinic lobe (rhinencephalon): The archicortex. Brain Res Bull 4: 1-108.

Jarvis JUM, Bennett NC. 1991. Ecology and behavior of the family Bathyergidae. In The biology of the naked mole-rat (ed. Sherman PW, Jarvis JUM, Alexander RD), pp. 6696. Princeton University Press, Princeton, NJ.

Johnson KM, Boonstra R, Wojtowicz JM. 2010. Hippocampal neurogenesis in food-storing red squirrels: The impact of age and spatial behavior. Genes Brain Behav 9: 583-591.

Kee N, Sivalingam S, Boonstra R, Wojtowicz JM. 2002. The utility of Ki-67 and BrdU as proliferative markers of adult neurogenesis. J Neurosci Meth 115: 97-105.

Kempermann G. 2012. New neurons for "survival of the fittest." Nat Rev Neurosci 13: 727-736.

Kempermann G, Gage FH. 2002. Genetic determinants of adult hippocampal neurogenesis correlate with acquisition, but not probe trial performance, in the water maze task. Eur J Neurosci 16: 129-136.

Kempermann G, Kuhn HG, Gage FH. 1997. More hippocampal neurons in adult mice living in an enriched environment. Nature 386: 493-495.

Kempermann G, Fabel K, Ehninger D, Babu H, Leal-Galicia P, Garthe A, Wolf S. 2010. Why and how physical activity promotes experience-induced brain plasticity. Front Neurosci 4: 189. 
Kim YP, Kim HB, Jang MH, Lim BV, Kim YJ, Kim H, Kim SS Kim EH, Kim CJ. 2003. Magnitude- and time-dependence of the effect of treadmill exercise on cell proliferation in the dentate gyrus of rats. Int J Sports Med 24: 114117.

Kim SK, Hwang IK, Yoo K-Y, Yoo DY, Bae E, Lee CH, Choi JH, Choi JW, Seong JK, Yoon YS, et al. 2010. Pregnancy inhibits cell proliferation and neuroblast differentiation without neuronal damage in the hippocampal dentate gyrus in C57BL/6N mice. Brain Res 1315: 25-32.

Klaus F, Amrein I. 2012. Running in laboratory and wild rodents: Differences in context sensitivity and plasticity of hippocampal neurogenesis. Behav Brain Res 227: $363-$ 370.

Klaus F, Hauser T, Lindholm AK, Cameron HA, Slomianka L, Lipp H-P, Amrein I. 2012. Different regulation of adult hippocampal neurogenesis in Western house mice (Mus musculus domesticus) and C57BL/6 mice. Behav Brain Res 227: 340-347.

Knoth R, Singec I, Ditter M, Pantazis G, Capetian P, Meyer RP, Horvat V, Volk B, Kempermann G. 2010. Murine features of neurogenesis in the human hippocampus across the lifespan from 0 to 100 years. PLOS ONE 5: e8809.

Kohler SJ, Williams NI, Stanton GB, Cameron JL, Greenough WT. 2011. Maturation time of new granule cells in the dentate gyrus of adult macaque monkeys exceeds six months. Proc Natl Acad Sci 108: 10326-10331.

Kornack DR, Rakic P. 1999. Continuation of neurogenesis in the hippocampus of the adult macaque monkey. Proc Natl Acad Sci 96: 5768-5773.

Kruska D. 1988. Effects of domestication on brain structure and behavior in mammals. Hum Evol 3: 473-485.

Kuhn HG, Dickinson-Anson H, Gage FH. 1996. Neurogenesis in the dentate gyrus of the adult rat: Age-related decrease of neuronal progenitor proliferation. J Neurosci 16: 2027-2033.

Kumazawa-Manita N, Hama H, Miyawaki A, Iriki A. 2013. Tool use specific adult neurogenesis and synaptogenesis in rodent (Octodon degus) hippocampus. PLoS ONE 8: e58649.

Lagace DC, Donovan MH, DeCarolis NA, Farnbauch LA, Malhotra S, Berton O, Nestler EJ, Krishnan V, Eisch AJ. 2010. Adult hippocampal neurogenesis is functionally important for stress-induced social avoidance. Proc Natl Acad Sci 107: 4436-4441.

Lavenex P, Steele MA, Jacobs LF. 2000. The seasonal pattern of cell proliferation and neuron number in the dentate gyrus of wild adult eastern grey squirrels. Eur J Neurosci 12: 643-648.

Lazic SE. 2012. Modeling hippocampal neurogenesis across the lifespan in seven species. Neurobiol Aging 33: $1664-$ 1671.

Lee DW, Miyasato LE, Clayton NS. 1998. Neurobiological bases of spatial learning in the natural environment: Neurogenesis and growth in the avian and mammalian hippocampus. Neuroreport 9: R15-R27.

Lee J, Duan W, Long JM, Ingram DK, Mattson MP. 2000 Dietary restriction increases the number of newly generated neural cells, and induces BDNF expression, in the dentate gyrus of rats. J Mol Neurosci 15: 99-108.
Lee J, Seroogy KB, Mattson MP. 2002. Dietary restriction enhances neurotrophin expression and neurogenesis in the hippocampus of adult mice. J Neurochem 80: 539547.

Leuner B, Mirescu C, Noiman L, Gould E. 2007. Maternal experience inhibits the production of immature neurons in the hippocampus during the postpartum period through elevations in adrenal steroids. Hippocampus 17: $434-442$.

Leuner B, Glasper ER, Gould E. 2010. Sexual experience promotes adult neurogenesis in the hippocampus despite an initial elevation in stress hormones. PLOS ONE 5: el1597.

Lieberwirth C, Wang Z. 2012. The social environment and neurogenesis in the adult mammalian brain. Front Hum Neurosci 6: el18.

Lieberwirth C, Wang Y, Jia X, Liu Y, Wang Z. 2013. Fatherhood reduces the survival of adult-generated cells and affects various types of behavior in the prairie vole (Microtus ochrogaster). Eur J Neurosci 38: $3345-$ 3355.

Llorens-Martín M, Torres-Aleman I, Trejo JL. 2006. Pronounced individual variation in the response to the stimulatory action of exercise on immature hippocampal neurons. Hippocampus 16: 480-490.

Lou SJ, Liu JY, Chang H, Chen PJ. 2008. Hippocampal neurogenesis and gene expression depend on exercise intensity in juvenile rats. Brain Res 1210: 48-55.

Lyons DM, Buckmaster PS, Lee AG, Wu C, Mitra R, Duffey LM, Buckmaster CL, Her S, Patel PD, Schatzberg AF. 2010. Stress coping stimulates hippocampal neurogenesis in adult monkeys. Proc Natl Acad Sci 107: 14823 14827.

Malmkvist J, Brix B, Henningsen K, Wiborg O. 2012. Hippocampal neurogenesis increase with stereotypic behavior in mink (Neovison vison). Behav Brain Res 229: 359 364.

Marín-Burgin A, Schinder AF. 2012. Requirement of adultborn neurons for hippocampus-dependent learning. $\mathrm{Be}$ hav Brain Res 227: 391-399.

Marino L. 2007. Cetacean brains: How aquatic are they? Anat Rec 290: 694-700.

Marlatt MW, Philippens I, Manders E, Czeh B, Joels M, Krugers H, Lucassen PJ. 2011. Distinct structural plasticity in the hippocampus and amygdala of the middle-aged common marmoset (Callithrix jacchus). Exp Neurol 230: 291-301.

Matsuo N, Kawamoto S, Matsubara K, Okubo K. 1998. Cloning and developmental expression of the murine homolog of doublecortin. Biochem Biophys Res Commun 252: $571-576$.

McEwen BS, Magarinos AM, Reagan LP. 2002. Structural plasticity and tianeptine: Cellular and molecular targets. Eur Psychiatry 17: 318-330.

Merritt JF. 2010. The biology of small mammals. The Johns Hopkins University Press, Baltimore.

Moser MB, Moser EI, Forrest E, Andersen P, Morris RG. 1995. Spatial learning with a minislab in the dorsal hippocampus. Proc Natl Acad Sci 92: 9697-9701. 


\section{Amrein}

Nacher J, Crespo C, McEwen BS. 2001. Doublecortin expression in the adult rat telencephalon. Eur J Neurosci 14: 629-644.

Naylor AS, Persson AI, Eriksson PS, Jonsdottir IH, Thorlin T. 2005. Extended voluntary running inhibits exerciseinduced adult hippocampal progenitor proliferation in the spontaneously hypertensive rat. J Neurophysiol 93: 2406-2414.

Ngwenya LB, Peters A, Rosene DL. 2006. Maturational sequence of newly generated neurons in the dentate gyrus of the young adult rhesus monkey. J Comp Neurol 498: 204-216.

Niethammer J, Krapp F. 1978. Handbuch der Säugetiere Europas [Manual of the mammals of Europe]. Rodentia, Vol. 1. Akademische Verlagsgesellschaft, Wiesbaden, Germany.

Ochocińska D, Taylor Jan RE. 2005. Living at the physiological limits: Field and maximum metabolic rates of the common shrew (Sorex araneus). Physiol Biochem Zool 78: $808-818$.

Olude AM, Olopade JO, Ihunwo AO. 2014. Adult neurogenesis in the African giant rat (Cricetomys gambianus, waterhouse). Metab Brain Dis 29: 857-866.

Ormerod BK, Galea LAM. 2001. Reproductive status influences cell proliferation and cell survival in the dentate gyrus of adult female meadow voles: A possible regulatory role for estradiol. Neuroscience 102: 369-379.

Pathania M, Yan LD, Bordey A. 2010. A symphony of signals conducts early and late stages of adult neurogenesis. Neuropharmacology 58: 865-876.

Patzke N, Kaswera C, Gilissen E, Ihunwo AO, Manger PR. 2013a. Adult neurogenesis in a giant otter shrew (Potamogale velox). Neuroscience 238: 270-279.

Patzke N, Olaleye O, Haagensen M, Hof P, Ihunwo A, Manger P. 2013b. Organization and chemical neuroanatomy of the African elephant (Loxodonta africana) hippocampus. Brain Struct Funct 219: 1-15.

Patzke N, Spocter M, Karlsson K, Bertelsen M, Haagensen M, Chawana R, Streicher S, Kaswera C, Gilissen E, Alagaili A, et al. 2015. In contrast to many other mammals, cetaceans have relatively small hippocampi that appear to lack adult neurogenesis. Brain Struct Funct 220: 361-383.

Pawluski JL, Galea LAM. 2007. Reproductive experience alters hippocampal neurogenesis during the postpartum period in the dam. Neuroscience 149: 53-67.

Peel MC, Finlayson BL, McMahon TA. 2007. Updated world map of the Köppen-Geiger climate classification. Hydrol Earth Syst Sci 11: 1633-1644.

Peragine DE, Simpson JA, Mooney SJ, Lovern MB, Holmes MM. 2014. Social regulation of adult neurogenesis in a eusocial mammal. Neuroscience 268: 10-20.

Ruscio MG, Sweeny TD, Hazelton JL, Suppatkul P, Boothe E, Carter CS. 2008. Pup exposure elicits hippocampal cell proliferation in the prairie vole. Behav Brain Res 187: 916.

Schaefers ATU. 2013. Rearing conditions and domestication background determine regulation of hippocampal cell proliferation and survival in adulthood-Laboratory $\mathrm{CD} 1$ and $\mathrm{C} 57 \mathrm{Bl} / 6$ mice versus wild house mice. Neuroscience 228: $120-127$.
Schmitz C, Hof PR. 2005. Design-based stereology in neuroscience. Neuroscience 130: 813-831.

Scholzen T, Gerdes J. 2000. The Ki-67 protein: From the known and the unknown. J Cell Physiol 182: 311-322.

Seress L, Abraham H, Tornoczky T, Kosztolanyi G. 2001. Cell formation in the human hippocampal formation from mid-gestation to the late postnatal period. Neuroscience 105: $831-843$.

Shors TJ, Anderson ML, Curlik Ii DM, Nokia MS. 2012. Use it or lose it: How neurogenesis keeps the brain fit for learning. Behav Brain Res 227: 450-458.

Siwak-Tapp CT, Head E, Muggenburg BA, Milgram NW, Cotman CW. 2007. Neurogenesis decreases with age in the canine hippocampus and correlates with cognitive function. Neurobiol Learn Mem 88: 249-259.

Slomianka L, West MJ. 2005. Estimators of the precision of stereological estimates: An example based on the CA1 pyramidal cell layer of rats. Neuroscience 136: $757-$ 767.

Slomianka L, Drenth T, Cavegn N, Menges D, Lazic SE, Phalanndwa M, Chimimba CT, Amrein I. 2013. The hippocampus of the eastern rock sengi: Cytoarchitecture, markers of neuronal function, principal cell numbers and adult neurogenesis. Front Neuroanatomy 7: 34 .

Spalding KL, Bergmann O, Alkass K, Bernard S, Salehpour M, Huttner HB, Boström E, Westerlund I, Vial C, Buchholz BA, et al. 2013. Dynamics of hippocampal neurogenesis in adult humans. Cell 153: 1219-1227.

Starborg M, Gell K, Brundell E, Höög C. 1996. The murine Ki-67 cell proliferation antigen accumulates in the nucleolar and heterochromatic regions of interphase cells and at the periphery of the mitotic chromosomes in a process essential for cell cycle progression. J Cell Sci 109: 143153.

Takamori Y, Wakabayashi T, Mori T, Kosaka J, Yamada H. 2014. Organization and cellular arrangement of two neurogenic regions in the adult ferret (Mustela putorius furo) brain. J Comp Neurol 522: 1818-1838.

Tonchev AB, Yamashima T. 2006. Differential neurogenic potential of progenitor cells in dentate gyrus and CA1 sector of the postischemic adult monkey hippocampus. Exp Neurol 198: 101-113.

Tonchev AB, Yamashima T, Zhao L, Okano HJ, Okano H. 2003. Proliferation of neural and neuronal progenitors after global brain ischemia in young adult macaque monkeys. Mol Cell Neurosci 23: 292-301.

Trut L, Oskina I, Kharlamova A. 2009. Animal evolution during domestication: The domesticated fox as a model. Bioessays 31: 349-360.

Vander Heiden MG, Cantley LC, Thompson CB. 2009. Understanding the Warburg effect: The metabolic requirements of cell proliferation. Science 324: 1029-1033.

van Praag H, Kempermann G, Gage FH. 1999. Running increases cell proliferation and neurogenesis in the adult mouse dentate gyrus. Nat Neurosci 2: 266-270.

Veenema AH, Cremers TIFH, Jongsma ME, Steenbergen PJ, de Boer SF, Koolhaas JM. 2005. Differences in the effects of 5-HT1A receptor agonists on forced swimming behavior and brain 5-HT metabolism between 
low and high aggressive mice. Psychopharmacology 178: $151-160$.

West MJ, Slomianka L, Gundersen HJ. 1991. Unbiased stereological estimation of the total number of neurons in the subdivisions of the rat hippocampus using the optical fractionator. Anat Rec 231: 482-497.

Wojtowicz JM. 2011. Adult neurogenesis in the hippocampus: Lessons from natural populations. In Neurogenesis in the adult brain l: Neurobiology (ed. Seki T, Sawamoto K,
Parent JM, Alvarez-Buylla A), pp. 257-270. Springer, Tokyo.

Zhu H, Wang ZY, Hansson HA. 2003. Visualization of proliferating cells in the adult mammalian brain with the aid of ribonucleotide reductase. Brain Res 977: $180-189$.

Zitnik G, Martin GM. 2002. Age-related decline in neurogenesis: Old cells or old environment? J Neurosci Res 70: $258-263$. 


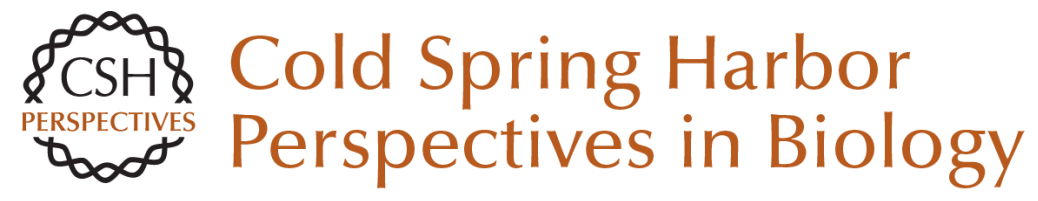

\section{Adult Hippocampal Neurogenesis in Natural Populations of Mammals}

Irmgard Amrein

Cold Spring Harb Perspect Biol 2015; doi: 10.1101/cshperspect.a021295

Subject Collection Neurogenesis

Adult Neurogenesis and Psychiatric Disorders Eunchai Kang, Zhexing Wen, Hongjun Song, et al.

Neuronal Circuitry Mechanisms Regulating Adult Mammalian Neurogenesis Juan Song, Reid H.J. Olsen, Jiaqi Sun, et al.

Neurogenesis in the Developing and Adult Brain

--Similarities and Key Differences Magdalena Götz, Masato Nakafuku and David Petrik

Genetics and Epigenetics in Adult Neurogenesis Jenny Hsieh and Xinyu Zhao

The Adult Ventricular-Subventricular Zone (V-SVZ) and Olfactory Bulb (OB) Neurogenesis Daniel A. Lim and Arturo Alvarez-Buylla

Diversity of Neural Precursors in the Adult Mammalian Brain Michael A. Bonaguidi, Ryan P. Stadel, Daniel A. Berg, et al.

Detection and Phenotypic Characterization of Adult Neurogenesis H. Georg Kuhn, Amelia J. Eisch, Kirsty Spalding, et al.

Maturation and Functional Integration of New Granule Cells into the Adult Hippocampus Nicolas Toni and Alejandro F. Schinder
Adult Olfactory Bulb Neurogenesis

Pierre-Marie Lledo and Matt Valley

Adult Neurogenesis in Fish Julia Ganz and Michael Brand

In Vitro Models for Neurogenesis Hassan Azari and Brent A. Reynolds

Engineering of Adult Neurogenesis and Gliogenesis

Benedikt Berninger and Sebastian Jessberger

Computational Modeling of Adult Neurogenesis James B. Aimone

Control of Adult Neurogenesis by Short-Range

Morphogenic-Signaling Molecules Youngshik Choe, Samuel J. Pleasure and Helena Mira

Adult Neurogenesis: An Evolutionary Perspective Gerd Kempermann

Epilepsy and Adult Neurogenesis

Sebastian Jessberger and Jack M. Parent

For additional articles in this collection, see http://cshperspectives.cshlp.org/cgi/collection/

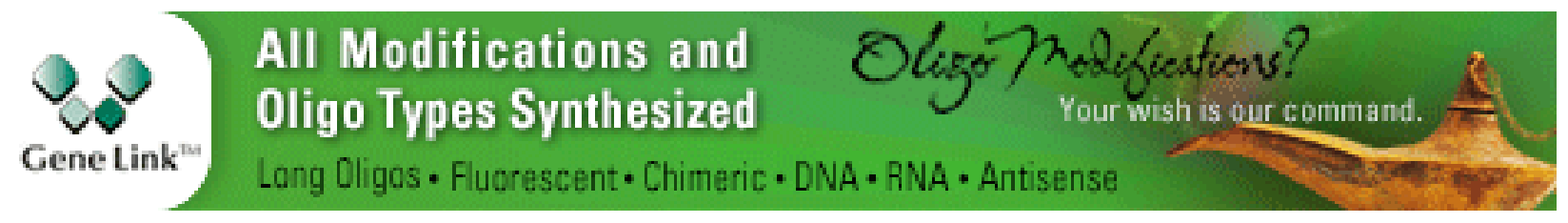

Copyright @ 2015 Cold Spring Harbor Laboratory Press; all rights reserved 